\title{
低出力レーザーによる星状神経節近傍への照射効果について
}

The Effect Low Power Laser Irradiation Around the Stellate Ganglion

\author{
吉沢 明孝, 清水 純一 ${ }^{*}$ \\ 要町病院内科, 理学療法科* \\ ₹171 東京都豊島区要町 $1-11-13$
}

Akitaka YOSHIZAWA and Junichi SHIMIZU*

Div, of Internal Medicine and Rehabilitaion*, Kanamechyo Hospital

要 旨

星状神経節近傍への低出カレーザーの照射は, 自律神経失調の患者において手背温を明らかに 上昇させた。頝部を圧迫しながらレーザーを照射したが，その効果は指任効果ではなかった。照 射反対側の温度上昇がみられた例はあったが体温上昇がみられた例はなく， systemicな温度上 昇とは考元にくく，その効果は血管神経系を介して血流を改善するための局所作用之考えられる。 そのため循環の不良な自律神経失調例に特に有効な成果が得られたと考元る。 キーワード；低出カレーザー，星状神経節，交感神経，指圧勃果

\begin{abstract}
The aim of this study was to evaluate the clinical effect of low power laser irradiation around the stellate gannlion in the neck. The hand temperature of the patients, who has disturbances of autonomic nervous system, was significantly increased after irradiation. Although we performed simple pressure stimulation of the stellate ganglion by laser tip, the hand temperature did not chang. In the recent studies, as a souce of hand temperature elevation, excess energy metabolism and blood stream have been documented. Therefore, we speculated that the mechanism of these changes may be due to the neurovascular responces through coat reaction of the autonomic nervous system.
\end{abstract}

Key ward: low power laser, stellate ganglion, autonomic nervous system, simple pressuer effect

今回我々は低出力レーザーの㞗状神経節近浐への照射 効果之適応を検討古べく，交感神経の過緊張状態上考え られる患者と健常者によるレーザ一照射の効果を比較検 討した。また圧迫しながらレーザーを照射したので，そ の効果が指压効果を持つか否かを検討した。

\section{対象, 方法}

対象は，要町病院理学療法科にて加療中の患者之健常 者で本実験の主旨に協力を得られた17名を対象とし以下 の3群に分けだ。

(1)患者群; 頸部から上肢にかけて盘れ, 痛み, 冷感の 
強い者 5 名, 疾患の内訳は外傷性頸椎症 2 名, 頸肩腕症 候群 1 名, 糖尿病性末梢神経障害 1 名, レイノ一症候群 1 名

(2)対照群；健常者10名

(3)非照射群；圧迫のみでレーザー光照射を施行しな かった者 7 名

レーザーは，泉工医科工業株式会社製He-Neレーザー 治療器を使用した。照射した星状神経節近傍は、解剖学 的には，図一 1 のごとく第 7 頸椎の横突起前方で下頸交 感神経節と第 1 胸交感神経節が䳸合し星状神経節を形成 しているのが通常で，第 6 頸椎位の中頸交感神経節とつ ながっている。照射方法は，左手の指示と中指で総頸部 動脈を外側に引き奇せ，乾部組織をわけて中指で第 6 頸 椎横突起の前結節を触れ，そこより尾側に約 $1-3 \mathrm{~cm} の$ 点, すなわち第 7 頸椎横突起基部を狙って照射した ${ }^{12 。 ~}$ この点は，胸鎖関節より約 $2.5 \mathrm{~cm}$ 上方，正中上り約 $1.5 \mathrm{~cm}$ 外側にあたる。星状神経節の前方には頸動脈が走ってお り，こ机を確実に圧排することが照射時の要点の1つと 思われる。照射時かなり強く王迫照射しており，また既 製品の先端では星状神経節なよ゙のスポットを狙いにくく， 我々が考案した図一2のごとくスポットを狙いやすく細 かく改良された特殊テーパガイドは正確な照射を可能に した。

そして，同側の手背温の变化を日本電気三栄社製 ニューサーモトレーサ６T67を用いて測定した。室温は，

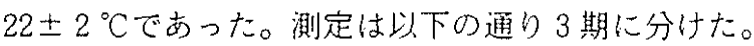

I 。照射前; 被検者を仰卧位で15分間安静状態にした時 の手背温の变化

II. 照射中；その後10分間星状神経節近倍に生迫照射し た時の手背温の変化

III. 照射後; 照射終了後10分間安静状態にした時の手背

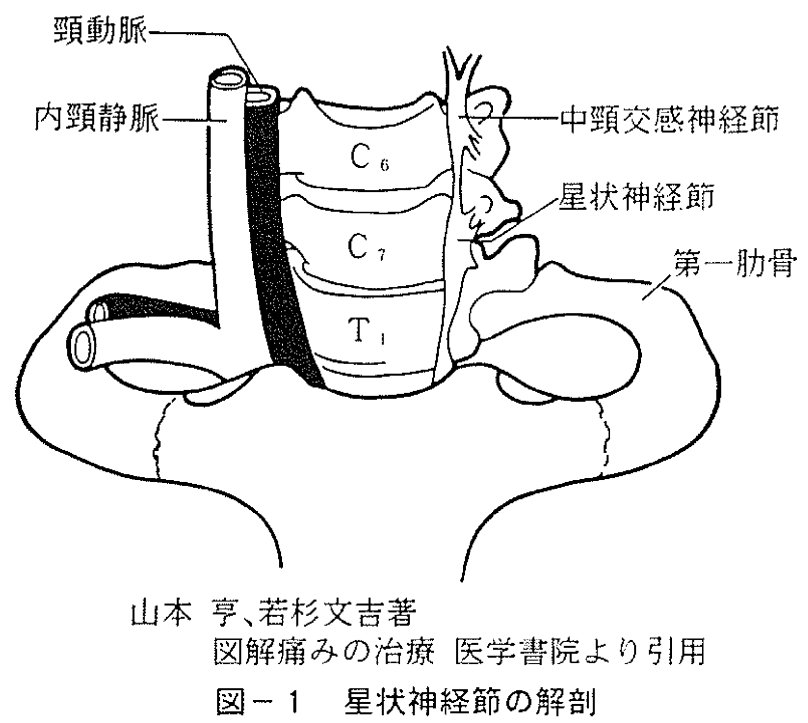

温の変化

各群の平均上昇率の变化はt-test, 群間比較は paired-t testにて統計処理した。

\section{結 果}

1. 各群における平均手背温の変化（図-3）

患者群では，入室時上り皮府温に開きが強くこれれ レイノー様症状を示した患者がおり，2名が $20^{\circ} \mathrm{C}$ 台の低 温を示していた為と考えられる。レーザー照射により対 照群，非照射群はほぼ同様の軽度の上昇を示しており， それに比べて患者群では強い上昇している。これを上界 率 $\left({ }^{\circ} \mathrm{C} / \mathrm{min}\right)$ で比較検討した。

2. 各群における平均手背温上界率の变化（図-4）

患者群では照射前の上昇率に比べて照射中，照射後の 上昇率上もに有意な差を示していたが，対照群，非照射 群では照射前の上昇率上照射中，照射後の上昇率に有意 な差はなかった。

3. 平均手背温上昇率の群間比較 (表-1)

表 1 群どうしの検定（t-TEST）

\begin{tabular}{|c|c|c|c|}
\hline & 照射前 & \multicolumn{1}{|c|}{ 照射中 } & 照射後 \\
\hline $\begin{array}{c}\text { 照射群 (患者) } \\
\text { - 照射群(対照群) }\end{array}$ & $\mathrm{N} \mathrm{S}$ & $\mathrm{P}<0.001$ & $\mathrm{P}<0.001$ \\
\hline $\begin{array}{c}\text { 照射群 (患者) } \\
\text { - 韭照射群 }\end{array}$ & $\mathrm{NS}$ & $\mathrm{P}<0.02$ & $\mathrm{P}<0.001$ \\
\hline $\begin{array}{c}\text { 照射群 (対照群) } \\
\text { 一非照射群 }\end{array}$ & $\mathrm{NS}$ & $\mathrm{N} \mathrm{S}$ & $\mathrm{N} \mathrm{S}$ \\
\hline
\end{tabular}

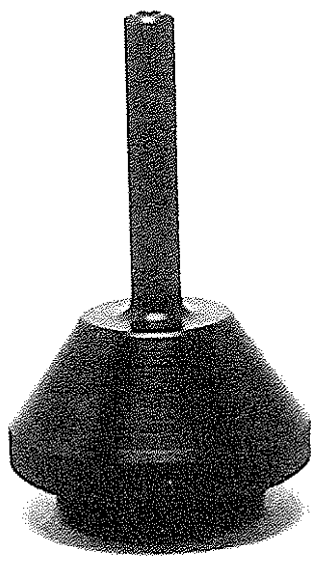

従来のテーパーガイドに比べ、先端部を 細く(真径 $7 \mathrm{~mm}$ )することで小さなポイント で皮府上から深部へ挿入することができる ため皮下深部への照射が可能。

$$
\text { 図ー2 特殊テーパガイド }
$$




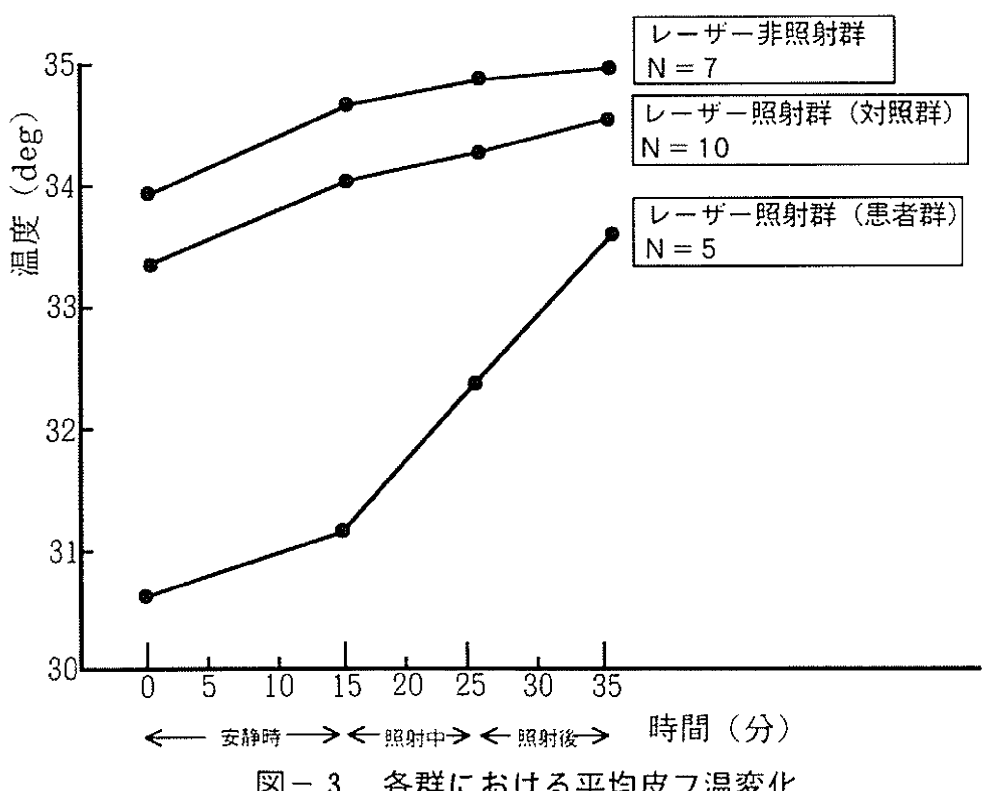

図一３＼cjkstart各群における平均皮つ温变化

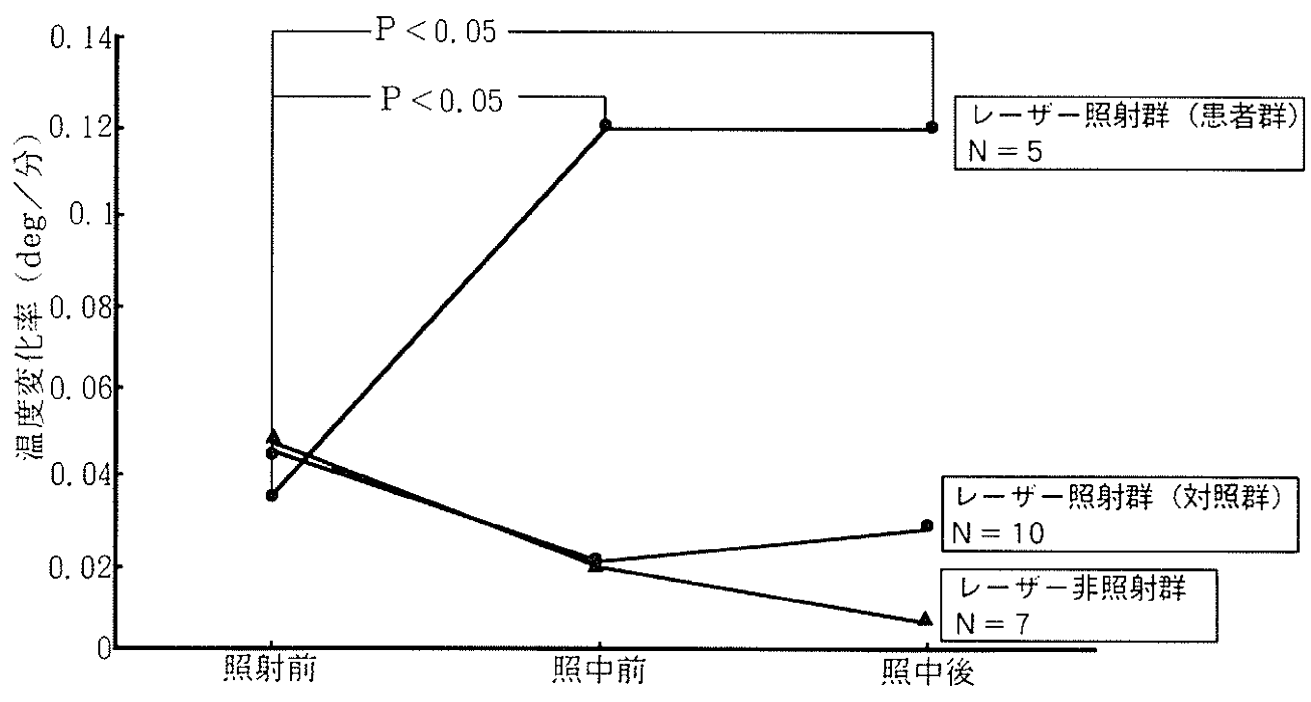

図一４各群における平均皮つ温变化率

群どうしの比较であるが，患者群と対照群，患者群と 非照射群との群間比較では，照射前では有意差はなく， 照射中と照射後に明らかな有意差が出現している。対照 群之非照射群の群間比較では, 照射前, 照射中, 照射後 のいずれにも有意差は見られなかった。

4. 対照群の同一被検者における照射上非照射の上昇 率の比較 (図-5)

3例ではあるが，照射と非照射の皮倠温の変動に有意 な差は認められなかった。

5. 患者群の同一被検者における照射之非照射の上昇 率の比較 (図-6)

2 例ではあるが，照射によって照射中，照射後に皮防 温の有意な上昇を認めたが、非照射では皮缶温に上昇は 認めら机なかった。
考 察

低出力レーザーによる痛みの治療については多くの報 告がなされている。そしてその有用性について疑いのな いところとなってきている。しかし，その作用機序につ いては未だに明らかではなく，多くの説が提起され検討 中である。その中には，(1)痛覚の神経制御機椣への影響， つまり下行性痛賞抑制系の元進作用 ${ }^{2.3)}$ 。(2)局所的な作 用上して自律神経系を介して血管昖張が起こり，血流增 加により除痛が得られるとするもの，消炎作用，疼痛閾 值の上昇など4-11) (3)免疫系賦活作用12.13) (4)疼痛の上 行性伝達抑制機序之して細胞膜の女定化作用 ${ }^{14.15) な と ゙, ~}$ 様々な仮説が提案されている。

照射法についても確立されたものはなく、レーザー照 射法の多くは，疼痛部位，神経走行上または経穴へのも のが多く行われてきた。レーザー治療について考えられ ている機序の1つに自律神経を介するものがあり，また 


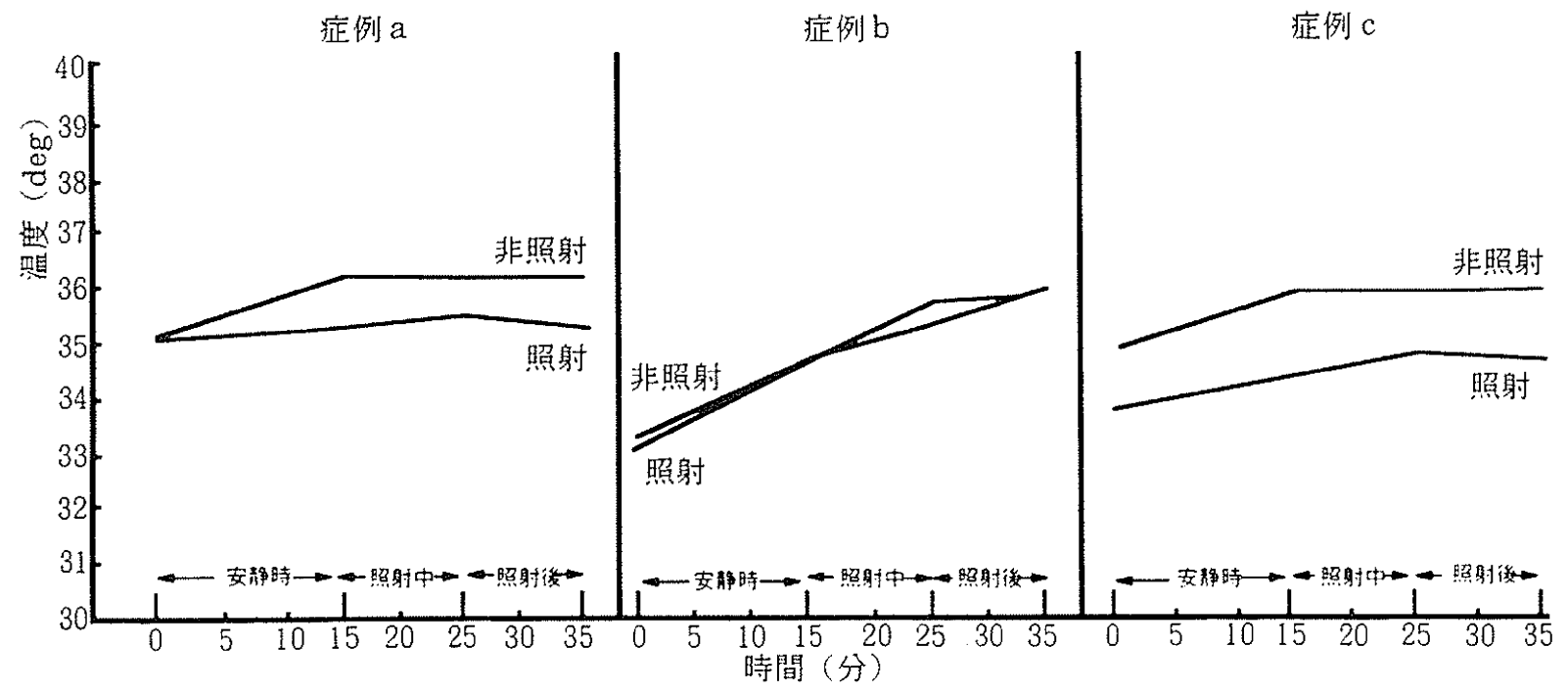

図－５同一被検者によるレーザー照射，非照射の比較 (対照群)

我々が日常ペインクリニックの臨床で痛みの機序とブ ロックの作用機序を考元る時, 痛みの悪循環という概念 がある。これは痛み刺激が知覚神経を介して脊噵を通っ て脳に達して痛みの自覚を生じさせ，それと同時に痛み

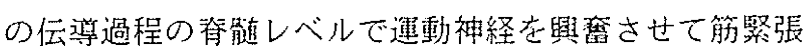
の増大を引き起こす。そして痛み刺激は交感神経, 副督 を刺激してカテコールアミンの分必を促し，血管の収縮 を起こし，疼痛部位に乏血状態を作り出す。乏血状態に なった組織では酸素不足のため通常之は異なった代謝が 行われるので bradykinine, serotonin などの発痛物質 が産生されるようになる。これらの発痛物筫が知覚神経 を刺激して新たな痛み刺激となり，痛みの伝導，認識が 繰り返さ机「痛みの悪循環」が起こるとする概念であ

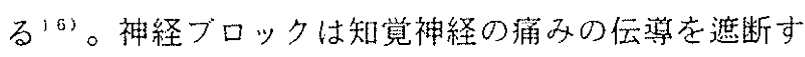
るばかりではなく, 涌みの悪循環の主因をなす交感神経, 運動神経にも直接作用し悪循環を全面的に断ち切るもの である。以上の理論に基づき我々は，交感神経ブロック が除痛に有効な例を数多く経験しているので, レーザー 照射の際においても痛みの部位への局所照射よりも星状 神経節近傍に対する照射の方が効果が強く現れるのでは ないかと期待した。今回の検討において対照群では，照 射前より仰臥位女静にすることで，緊張状態が緩和され， 心臟の位置関係により体内血流分布の变化が起こり手背 温の上昇がみられることが多く，照射中，照射後に照射

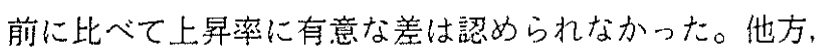
交感神経が病的過緊張状態にあり身体の恒常性の乱れた 患者群では，照射前の上昇率に比較して照射中，照射後 の上昇率に有意な差を認め，これはレーザー照射が痛み の悪循環理論で考えられる交感神経の過緊張を抑制し組 織の乏血状態を改善するため手背温を上昇させたものと 考えられる。

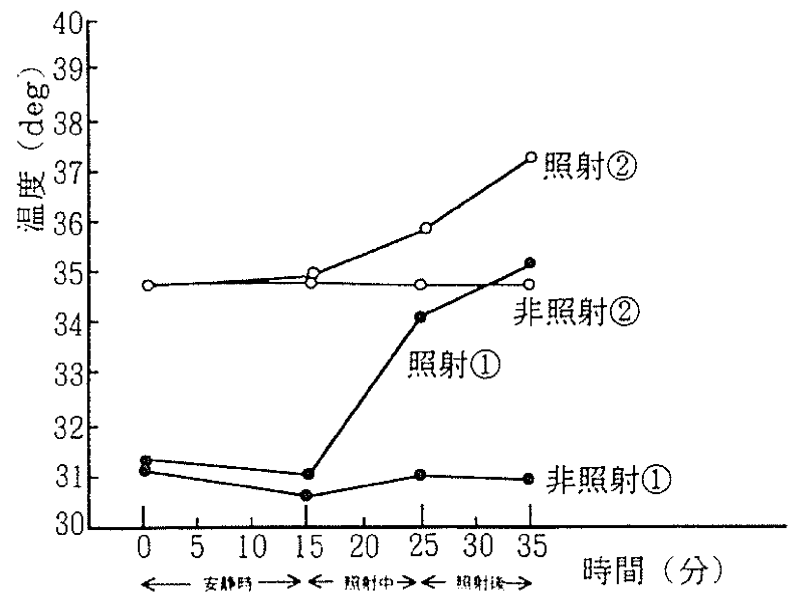

図一６同一患者によるレーザー照射，非照射の比較 (患者)

またレーザー照射後反対側の手背温の上昇を認めた例 もあったが，体温の上昇を示した例はなく、この手背温 の上昇はsystemicな作用と言うよりも温度を運ぶ血流 および血管系が主体をなすものと考えられた。そして レーザー照射は血管神経系を介して血流を改善するため に，特に自律神経失調例に有効であったと考えられた。 しかし局所麻酔䯇による星状神経節ブロックの上うに顔 面，上肢の温感を訴える患者はいてもホルネルの徵候や 鼻閉，嗄声などの神経㵂断による症状を訴えた患者は一 人もいなかった。このことは、レーザー照射では神経ブ ロックのように交感神経麻疩又は抑制するのではなく， 過緊張状態を正常に近い状態に戻すまでにとどまるもの と思わ机，無侵留という点においても今後も広く応用さ れるべき痛みの治療法であると考えられる。レーザー照 射をせずに星状神経節近傍の圧迫のみを行った非照射群 の検愊も行ったが，対照群上比較して手背温の上界率に 有意な差は見られなかった。健常な同一被唡者に上る検 討を 3 例に実施したが，照射，非照射上もに手背温は同 
じような変動を示した。これに対して2 例の患者では照 射によって照射中，照射後に有意の温度上昇が喼められ た。以上の結果からレーザー照射の効果は圧迫による指 圧によるものではないと判断した。

\section{結 果}

レーザーの星状神経節近傍への照射による手背温の变 化は自律神経の過緊張状態にある患者群でのみ有意に上 昇していた。またこのレーザーの照射効果には圧迫によ る指圧効果を伴わないものと考えられる。

本論文の要旨は第 2 回日本低エネルギーレーザー会議 (1989東京)，第37回日本麻酔学会総会 (1990長野)，第 2 回国際低出力レーザー会議(1990東京), 第11回日本 レーザー医学会大会（1990金沢）にて発表した。

\section{参考文献}

1) 山本亭, 若杉文吉; 図解痛办の治療 東京医学幚院 2 版 109-110, 1985 .

2) Walker, $J$; Relief from chronic pain by laser irradiation. Neurosci. Lett. 43 ; 339-344, 1983.

3) 山本博之, 尾崎昌宣, 井口賀之, 他：ラットにおけ る経穴レーザー照射の鎮痛効果，ペインクリニック， $8: 43-48,1987$.

4) 篠原秀樹, 加蔡治文, 小中千守, 他; Ga-Al-As半 薪体レーザーによるレーザー刺激療法，ペインクリ ニック. $8: 12-17,1987$.

5）神川喜代男，大西俊輝，鈴木正根，他; 痛子に対吉 るレーザー治療，ペインクリニック，8:12-17，1987.

6）飯島一彦, 清水俊行, 水口公信, 他; 疼涌外来に打 ける低出力レーザーの有用性の検討, 日本レーザー 医学会誌， $9 ： 3-10,1988$.

7) 大西俊輝，神川喜代男：レーザー針装㽞の開発とそ

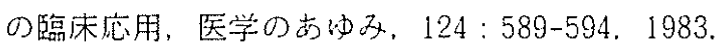

8) 神川喜代男, 他; 低出力レーザー治療よサーモグラ ム、日本レーザー医学会誌，6：47-52，1986.

9)圆島行一, 茂手木三男, 原田孝, 他; 整形外科領域 における低エネルギーレーザーの治療経験：ペイン クリニック, $8: 23-28,1987$.

10) 西田澋；ヘリウムーネオン・レーザー照射のリウマ 千罹患関節滑膜に及ばす效果の組織学的検討，リウ マチ, $28: 109-117,1988$.

11）柳瀬昌弘, 本村明江, 坂巻玲子, 他 ; カラニゲン炎 症における低出力半尊体レーザーの鎮痛効果，ペイ ンクリニック， $8: 39-42,1987$.

12) Klima, H., Schindl, L. ; Immunorogical aspects of laser therapy, In Abstracts of 7 th Congress of the International Society for Laser Surgery and Medicine. No, 212, 1987.

13) Seminon, R., Morris, R., Moshe, N. et al, ; Systemic effects of low power laser irradiation on the peripheral and central nervous system, cutaneous wounds and burns. ; Lasers Surg. Med. : 9, 174-182, 1989.

14) Kubasova, T. et al. ; Biological effect of $\mathrm{He}-\mathrm{Ne}$ laser., Lasers Surg. Med. 4 : 381-388, 1984.

15) Walker, J. B, Akhanjee, L. k. ;Laser-induced somatosensory evoked potentials : Evidence of photosensitivity in peripheral nerves, Brain Res., 344 : 281-285, 1985.

16）天羽敬裙監修, 山室誠著; 図説痛みの治療入阴, $3-6 ;$ 中外医学社 ; 1984 